\title{
Tinjauan Strategi Komunikasi Program Edutainment di Televisi
}

\author{
Angel Dinata, Eko Harry Susanto, Sudarto \\ angel.dinata88@gmail.com,ekos@fikom.untar.ac.id,antosudarto@gmail.com
}

Fakultas Ilmu Komunikasi Universitas Tarumanagara

\begin{abstract}
Oh Gitu is one of the Edutainment genre programs that aired on Trans Tv television station. Oh Gitu has a goal to educate while entertaining his audience by choosing hosts from comedians. Information about public service, the production of a product, to the unique information about a culture that is still rarely known by people, is packed lightly by Oh Gitu. But unfortunately after 3 months from its premiere in November 2019, Oh Gitu had to stop airing at the end of February 2020. The purpose of this research is to determine the cause of the program Oh Gitu to stop airing and to know what kind of strategy the team is doing in an effort to attract the audience. In this research authors use qualitative methods of case studies to help achieve research results. Authors use data collection methods from interviews, Internet data observation, and data documentation. The results of this research author found that the edutainment program Oh Gitu stopped airing because more people are interested in pure entertainment program, decreased program rating, and strategy mistakes in promoting the program. And the authors hope, this research can be beneficial for Trans $T v$ in the future to be able to maximize the impressions and programs that educate for many people.
\end{abstract}

Keywords: television programs, Edutainment, strategy, watching interest.

\begin{abstract}
Abstrak
Program Oh Gitu merupakan salah satu program bergenre Edutainment yang tayang di stasiun televisi Trans Tv. Oh Gitu memiliki tujuan untuk mengedukasi sekaligus menghibur penontonnya dengan memilih host dari kalangan komedian. Informasi mulai dari pelayanan umum, produksi suatu produk sampai informasi unik mengenai suatu budaya yang masih jarang diketahui oleh orang, dikemas secara ringan oleh Oh Gitu. Namun sayang setelah 3 bulan dari tayang perdananya bulan November 2019, Oh Gitu harus berhenti tayang pada akhir bulan Februari 2020. Tujuan penelitian ini adalah untuk mengetahui penyebab program $\mathrm{Oh}$ Gitu berhenti tayang dan untuk mengetahui strategi seperti apa yang dilakukan oleh tim dalam upaya menarik minat menonton masyarakat. Dalam penelitian ini penulis menggunakan metode kualitatif studi kasus untuk dapat mencapai hasil penelitian. Penulis menggunakan metode pengumpulan data dari hasil wawancara, observasi data internet, dan dokumentasi data. Hasil penelitian ini penulis menemukan bahwa program edutainment Oh Gitu berhenti tayang karena lebih banyak masyarakat yang tertarik dengan program pure entertainment, menurunnya rating tayangan, dan kesalahan strategi dalam mempromosikan program. Dan penulis berharap penelitian ini dapat bermanfaat bagi Trans Tv kedepannya untuk dapat memaksimalkan tayangan dan program yang mengedukasi bagi masyarakat.
\end{abstract}

Kata Kunci: program televisi, edutainment, strategi, minat menonton.

\section{Pendahuluan}

Televisi merupakan salah satu media mainstream yang masih banyak peminatnya ditengah zaman yang serba digital ini. Seringkali televisi menjadi media yang terpercaya di tengah maraknya hoax yang begitu banyak tersebar di Internet. Survey IDN Research Institute menunjukkan 89\% milenial di Indonesia pada tahun 2019 masih menonton televisi, lalu diikuti video online, seperti di Youtube dan Instagram dengan persentase 46\% (IDN Research Institute 2019). Televisi memberikan informasi kepada masyarakat, melalui tayangan seolah-olah memindahkan realitas sebenarnya atas suatu kejadian kedalam layar. Keberadaan televisi yang 
diciptakan sebagai media komunikasi massa sudah melekat dalam kehidupan masyarakat modern dan dianggap dapat memenuhi kebutuhan informasi berita dan hiburan yang dibutuhkan (Susanto, 2010). Dalam dunia pertelevisian membuat program acara yang menarik adalah suatu keharusan agar stasiun televisi terus ada, mengundang banyak penonton dan kemudian dapat mengundang banyak iklan masuk di stasiun televisinya.

Namun sering kali demi mementingkan rating dan bertahan dalam persaingan, televisi malah menyajikan program yang kurang mendidik bagi masyarakat, minim etika dan tidak tepat sasaran audiensnya (Paramitha, 2014). Meskipun demikian, tetap masih ada juga tayangan yang mendidik bagi penontonnya, salah satunya adalah program hiburan edukasi Oh Gitu yang tayang di Trans Tv.

Keunikan dari program "Oh Gitu" adalah mengibaratkan reaksi seseorang ketika mendapat informasi baru mengenai suatu hal yang akan berkata "Oh Gitu cara buatnya", "Oh Gitu ternyata prosesnya". Oh Gitu menyajikan tayangan menarik mengenai informasi mulai dari pelayanan umum, produksi suatu produk sampai informasi unik mengenai suatu budaya yang masih jarang diketahui oleh orang. Menambahkan bauran komedi dalam setiap penyampaian informasinya, Oh Gitu memilih host dari kalangan komedian yakni Mpok Alpa dan Aziz Gagap yang berasal dari program komedi Opera Van Java yang ada di Trans 7.

Ketika membuat suatu program televisi tim harus membuat strategi yang berguna sebagai acuan untuk menarik minat penonton, baik strategi dalam proses pembentukan konten maupun strategi dalam menarik minat penonton. Dalam proses perencaan program, produser dan tim harus memperhatikan sisi kekuatan, kelemahan, peluang dan ancaman program tersebut. Dengan menggunakan analisis SWOT (Strength, Weakness, Opportunities, Threats) tim dapat mengindentifikasi kekuatan dan peluang program tersebut supaya dapat menarik audien serta melihat dan meminimalisir kelemahan dan ancaman dari program tersebut misalnya memperhatikan pesaing dari program acara tersebut.

Berbicara tentang strategi berarti berbicara juga tentang target. Ketika merencanakan suatu program produser dan tim harus menentukan target audiensnya yang nanti akan berpengaruh kepada isi konten program dan jam tayang program. Pengelola program harus mengetahui siapa audien yang menonton televisi pada waktu-waktu tertentu. Mengetahui audien televisi pada waktu tertentu sangat penting dalam menentukan program yang akan ditayangkan dan juga penting bagi pemasang iklan (Morissan, 2018:295).

Setelah perencanaan selanjutnya adalah produksi program, dalam tahap ini produser dan tim membuat gagasan konten yang sesuai dengan karakter dari program itu sendiri, setelah dibuat ide konten dan sudah disetujui oleh berbagai pihak yang bersangkutan baru nanti dilakukan yang namanya produksi dalam bentuk shooting editing dan sebagainya (Morissan, 2008:266).

Langkah selanjutnya yakni eksekusi program mencakup kegiatan menayangkan program di televisi sesuai dengan rencana yang sudah ditetapkan (Morrisan, 2008; 299). Eksekusi ini merupakan proses pelaksanaan dari rencana program yang telah dibuat. Eksekusi program hendaknya dibuat sedemikian rupa agar tidak menyimpang terlalu jauh dari perencanaan semula. Tahap terakhir yang tidak kalah penting dari ketiga tahap diatas yakni pengawasan dan evaluasi program. Proses pengawasan dan evaluasi menetukan seberapa jauh suatu rencana dan tujuan sudah data dicapai atau diwujudkan oleh stasiun penyiaran, departemen, dan karyawan. Kegiatan evaluasi secara berkala terhadap masing- masing anggota tim dan departemen memungkinkan manajer umum membandingkan kinerja yang direncanakan dengan hasil kinerja dilapangan. Jika kedua kinerja tersebut tidak sama, maka diperlukan langkahlangkah perbaikan (Morissan, 2008: 314).

Program Oh Gitu di Trans Tv memiliki durasi tayang selama 30 menit dan memiliki jadwal tayang setiap hari Sabtu dan Minggu pukul 15.30 WIB 'Oh Gitu' bersaing dengan beberapa stasiun televisi dalam menarik minat menonton khalayak. Namun harus disayangkan 
program Oh Gitu yang mulai tayang pada 23 November 2019 harus berhenti produksi pada tanggal 23 Februari 2020. Padahal menurut penulis program tersebut memberikan dampak positif dalam hal mengedukasi masyarakat lewat tayangannya, khususnya dalam hal informasi tentang pelayanan umum yang sering kita temui dikehidupan sehari-hari.

Maka dari itu penelitian ini dilakukan dengan tujuan untuk mengetahui penyebab program Oh Gitu berhenti tayang dan untuk mengetahui kesalahan strategi serta strategi seperti apa yang sudah dilakukan oleh tim dalam upaya menarik minat penonton dan mempertahankan program Oh Gitu. Supaya dikemudian hari jika ada tayangan yang serupa, kesalahan yang sama tidak terulang kembali.

\section{Metode Penelitian}

Dalam penelitian ini, penulis menggunakan pendekatan kualitatif untuk dapat mencapai hasil penelitian. Dengan menggunakan metode penelitian studi kasus yang meneliti fenomena kontemporer (pada masa kini) secara utuh dan menyeluruh pada yang kondisi yang sebenarnya dan menggunakan data berbagai sumber data (Arikunto, 2010). Dalam hal ini adalah studi kasus terhadap program Oh Gitu di Trans Tv yang sekaligus menjadi objek dalam penelitian ini. Objek penelitian merupakan suatu sasaran ilmiah untuk mendapatkan data dengan tujuan dan kegunaan tertentu tentang suatu hal subjektif, valid dan reliable tentang suatu hal (variable tertentu) (Sugiyono 2010:213). Sedangkan subjek penelitian merupakan subjek yang dituju oleh peneliti sebagai penelitian. Dalam penelitian kualitatif, subjek penelitian sering disebut juga dengan istilah informan (Sugiyono, 2010:216). Subjek dalam penelitian ini adalah produser, tim kreatif, tim promosi program Oh Gitu serta tim PR Trans Tv. Dalam pengumpulan data, penulis menggunakan metode pengumpulan data primer dan sekunder Data Primer merupakan sumber data yang langsung memberikan data kepada pengumpul data (Sugiyono 2016:225). Dalam pengumpulan data primer penulis melakukan wawancara dengan subjek penelitian dan observasi internet mengenai program Oh Gitu. Sedangkan data sekunder merupakan sumber data yang tidak langsung didapat oleh pengumpul data misalnya melaui orang lain atau lewat dokumen (Sugiyono, 2016:225). Untuk memperoleh data sekunder, penulis menggunakan data yang bersumber dari buku-buku dan data online mengenai program Oh Gitu yang didapat dari media online. Untuk analisis data penulis menggunakan tiangulasi sumber yaitu pengecekkan data yang telah diperoleh melaui berbagai sumber dan triangulasi teknik yaitu penulis menggunakan teknik pengumpulan data yang berbeda- beda untuk mendapatkan data dari sumber yang sama. Teknik pengumpulan data yang dimaksud berupa wawancara, observasi dan dokumentasi untuk sumber data yang sama secara serentak (Sugiyono 2016:241). Dengan kata lain penulis membandingkan hasil wawancara dengan data yang penulis dapatkan.

\section{Hasil Temuan Dan Diskusi}

Oh Gitu merupakan program baru Trans Tv yang bertujuan untuk memberikan edukasi kepada masyarakat berbagai macam informasi mulai dari pelayanan umum, produksi suatu produk sampai informasi unik mengenai suatu budaya. Memiliki slogan "yang gak paham jadi paham, dan yang gatau jadi tau", Oh Gitu mengemas informasi dengan balutan komedi (https://www.Trans Tv.co.id). Dipandu dengan dua komedian yang berasal dari program komedi unggulan Trans 7 Opera Van Java, yakni Mpok Alpa dan Aziz Gagap. Oh Gitu memberikan informasi terbaru kepada masyarakat mengenai hal-hal unik yang terjadi dikehidupan seharihari dan jarang diketahui oleh masyarakat. Program Oh Gitu menjadi salah satu program unggulan awal tahun 2020 yang dimiliki oleh Trans Tv (Sumber: Detik.com/Infotainment).

\section{Penyebab program - hiburan edukasi ‘Oh Gitu’ di Trans Tv kalah bersaing}


Dalam dunia pertelevisian pasti ada yang namanya persaingan antar stasiun televisi. Masing- masing stasiun televisi berlomba-lomba membuat program unggulan untuk dapat menarik penonton sebanyak mungkin. Berdasarkan hasil wawancara penulis dengan tim kreatif Oh Gitu, penulis mendapatkan fakta bahwa minat penonton cenderung lebih banyak kepada program entertain seperti gossip, makanan dan sebagainya.

Selain karena minat penonton lebih banyak ke program gosip, faktor lain yang mempengaruhi program Oh Gitu kalah bersaing adalah pemilihan jam tayang dari program $O h$ Gitu. Selama penayangannya Oh Gitu sempat mengalami beberapa perubahan jam tayang, hal tersebut dikarenakan adanya pergeseran jadwal program karena adanya penambahan program dan menyesuaikan jam tayang program untuk mencapai share dan rating yang terbaik. Target audiens dari program Oh Gitu adalah semua umur, Walaupun Oh Gitu memiliki target audien semua umur, namun menurut penulis kontennya kurang berhasil memikat banyak kaum anakanak dan remaja. Berdasarkan penelusuran penulis anak-anak dan remaja akan lebih tertarik untuk menyaksikan tayangan kartun dan sinetron yang ada di stasiun tv lain yang tayang di jam yang sama.

Lebih banyaknya minat menonton masyarakat terhadap program hiburan seperti gossip, kurangnya minat menonton masyarakat terhadap program berbasis edukasi dan kurang tepatnya penempatan jam tayang program Oh Gitu. Hal tersebutlah yang membuat program Oh Gitu kalah bersaing.

\section{Penyebab Berhentinya Tayangan Program Hiburan-Edukasi Oh Gitu}

Jika membahas tentang televisi share \& rating adalah hal yang tidak bisa dipisahkan. Salah satu lembaga yang konsen terhadap kegiatan di televisi adalah lembaga Nielsen. Singkatnya Nielsen adalah sebuah perusahaan informasi dan pengukuran global. Di Indonesia sendiri Nielsen dikenal dengan nama Nielsen TAM (Television Audience Measurement). Rating adalah jumlah penonton suatu program dibagi populasi televisi (seleruh penonton), sedangkan share adalah jumlah penonton suatu program dibagi orang yang menonton pada saat itu (sumber: www.nielsen.com/id).

Rating juga ditentukan dari berbagai aspek misalnya dari konten suatu program, tokoh yang membawakan, jam tayang, dan masih banyak lagi. Dalam penelitian ini program hiburanedukasi Oh Gitu dalam konsep awalnya adalah ingin menghadirkan suatu tayangan yang mengedukasi sekaligus juga menghibur dengan menghadirkan host dari kalangan komedian. Hal tersebut penulis dapatkan ketika melakukan wawancara dengan Esta tim kreatif dari program Oh Gitu. Dan salah satu faktor yang membuat tim semula optimis dengan program Oh Gitu adalah pemilihan salah satu host yang sedang naik daun yakni Mpok Alpa yang datang dari acara Opera Van Java di Trans 7.

Pemilihan suatu pembawa acara untuk mendukung rating tidak bisa hanya melihat dari sisi terkenalnya saja, namun harus sesuai dengan karakter dari program tersebut. Oh Gitu mempunyai konsep ingin memberi tahu kepada masyarakat hal-hal yang sering ditemui dalam kehidupan sehari-hari tapi masyarakat belum tahu banyak. Produser Oh Gitu mengatakan alasan memilih Mpok Alpa karena menurutnya Mpok Alpa dapat mewakili kelompok masyarakat female yang kritis tapi gak tau banyak, sedangkan Aziz Gagap lebih mewakili dari sisi komedi dan juga karena sifat aslinya yang tertarik dengan hal-hal yang baru. Dan menurut penulis konsep dari program Oh Gitu dan pemilihan host sudah sangat pas dan sesuai dengan karakter dari program Oh Gitu sendiri. Berikutnya yang penting juga untuk menarik minat penonton adalah konten. Konten merupakan isi dari suatu program. Konten biasanya dibuat oleh tim kreatiif dari program tersebut yang kemudian konsep dari konten tersebut diajukan kepada produser dan setelah diterima konsepnya baru bisa mulai proses shooting. Kendala yang dialami oleh Tim dari program Oh Gitu adalah sulitnya mencari tempat dan objek pembahasan yang 
sesuai dengan standart Oh Gitu (yang bener-bener orang gak tahu).

Akbar selaku tim kreatif dari program Oh Gitu juga menceritakan kepada peulis kendala selama proses pembuatan konten Oh Gitu. Ia menjelaskan bahwa perbedaan jam tayang dua kali seminggu dan tujuh kali seminggu adalah kematangan dari konsep. Jadi pada saat Oh Gitu tayang dua kali seminggu, riset yang dilakukan dapat dilakukan dengan lebih maksimal dan konsep akan lebih matang.

Oh Gitu sempat meluaskan konten ke inspirasi usaha, bekerja sama dengan beberapa brand seperti Kopi Kenangan, Trevo dan masih banyak lagi. Hal tersebut dilakukan oleh tim untuk menyiasati konten-konten yang memiliki kendala dengan perizinan. Pergantian host program Oh Gitu juga pernah dilakukan dalam usaha mempertahankan program Oh Gitu.

Jadi faktor internal yang menyebabkan program Oh Gitu berhenti tayang adalah kesulitan mencari objek pembahasan yang sesuai dengan standart program Oh Gitu dan kematangan konsep dari segi informasi yang dibahas maupun dari segi komedi, dengan jumlah tim yang tidak banyak. Sedangkan faktor eksternalnya adalah menurunnya share dan rating dari program Oh Gitu.

\section{Kesalahan Strategi Program Oh Gitu dalam Menarik Minat Menonton}

Keberhasilan suatu program juga ditentukan dari kegiatan promosi program tersebut. Promosi adalah sejenis komunikasi yang memberi penjelasan tentang keunggulan produk yang menyakinkan calon konsumen tentang produk tersebut (Buchari Alma, 2012: 179). Definisi promosi jika dikaitkan dengan promosi program adalah kegiatan yang dilakukan untuk memasarkan dan memberitahukan kepada calon penonton informasi tentang suatu program.

Promosi program televisi biasanya dilakukan lewat iklan tayangan program yang diletakan ditengah-tengah iklan komersil selain itu promosi program biasanya juga dilakukan oleh Public Relations dari stasiun tv tersebut. Dalam penelitian ini Trans Tv menggunakan Public Relations divisi media sosial untuk membantu promosi setiap program yang ada di Trans Tv lewat media sosial.

Dalam penelitian ini strategi promosi program Oh Gitu dilakukan dengan cara pertama, promosi lewat media sosial (instagram, facebook, dan twitter Trans Tv). Kedua, bekerja sama dengan PR untuk membuat kuis tebak-tebakan di Instagram Trans Tv mengenai program $O h$ Gitu (namun sayang ketika penulis menelusuri instagram Trans Tv ternyata hanya satu kali promosi dalam bentuk kuis seperti ini dan itu juga diposting pada tanggal 30 Desember 2019). Ketiga, membuat press release acara unggulan yang ada di Trans Tv dan artikel barupa berita program baru yang ada di Trans Tv.

Jadi kesalahan strategi program Oh Gitu dalam menarik minat menonton terletak pada kurangnya tim promosi dalam hal ini tim kreatif dan tim PR Trans Tv dalam memaksimalkan promosi program lewat media sosial dan internet. Hal-hal yang berpotensi menarik minat menonton hanya dilakukan sesekali saja oleh tim promosi.

\section{Simpulan}

Dalam penelitian ini, program hiburan-edukasi Oh Gitu di Trans Tv berusaha untuk mengedukasi penontonnya namun dengan cara baru dan berbeda yakni, mengkombinasikan unsur pengetahuan umum dengan unsur komedi dengan memilih host dari kalangan komedian. Namun dalam prakteknya ternyata program Oh Gitu kurang mendapat minat di hati masyarakat Indonesia. Strategi seperti perubahan jam tayang, penambahan hari tayang dari dua kali menjadi tujuh kali seminggu, perluasan konten, pergantian host, promosi lewat semua media sosial Trans Tv, di 
Youtube Trans Tv, ternyata belum ampuh untuk menarik minat penonton dan mempertahakan program Oh Gitu. Sehingga program tersebut harus berhenti tayang setelah tiga bulan dari tayangan episode perdananya.

Komunikasi antar departemen, dalam hal ini adalah tim dari suatu program televisi dengan tim Public Relations televisi sangatlah penting dan harus saling mendukung. Konsep promosi dari program harus dibentuk dan disampaikan secara tepat dan jelas kepada orang yang melakukan promosi tersebut. Sehingga nantinya promosi program dapat berjalan dengan baik dan diharapkan mempu menarik minat penonton untuk menonton program tersebut.

\section{Ucapan Terima kasih}

Pada kesempatan ini, kepada Tuhan YME, keluarga, kepada seluruh Dosen Fakultas Ilmu Komunikasi Tarumanagara, narsumber program Oh Gitu dan PR Trans Tv, serta temanteman penulis, penulis mengucapkan terima kasih kepada seluruh pihak yang telah penulis sebutkan karena telah mendukung dan membantu peneliti selama proses penelitian sampai akhir penulisan artikel ini.

\section{Daftar Pustaka}

Arikunto, Suharsimi. (2010). Prosedur Penelitian Suatu Pendekatan Praktik. Jakarta: Rineka Cipta.

Alma, Buchari. (2012). Manajemen Pemasaran dan Pemasaran Jasa. Bandung:

Hanya 13\% masyarakat yang masih mendengarkan radio. (2019, Oktober 23). Februari 20, 2020. https://databoks.katadata.co.id/datapublish/2019/10/23/hanya-13-persen-masyarakatyang-masih-mendengarkan-radio

Komisi Penyiaran Indonesia (2017). Hasil Survei Indeks Kualitas Program Siaran Tv. Februari 20, 2020. http://www.kpi.go.id/download/penelitian/Ekspose_Survei_II tahun 2017

Lubis, Hadransyah. (2020, Januari 27). Deretan Program Unggulan Trans Tv 2020. Mei 26, 2020. https://www.transtv.co.id/corporate/press-release/120/deretan-program-unggulantrans- tv-2020

Morissan (2008). Manajemen Media Penyiaran: Strategi Mengelola Radio \& Televisi. Jakarta: Kencana.

Morissan. (2018). Manajemen Media Penyiaran: Strategi Mengelola Radio \& Televisi (ed revisi). Jakarta: Prenada Media.

Paramita, Sinta. (Februari 2014). Komunikasi Media dan Budaya Melahirkan Spectacle Society.

Sugiyono. (2010). Metode Penelitian Pendidikan Pendekatan Kuantitatif, Kualitatif, dan R\&D. Bandung: Alfabeta.

Sugiyono. (2016). Metode Penelitian Pendidikan Pendekatan Kuantitatif, Kualitatif, dan R\&D. Bandung: Alfabeta.

Susanto, Eko Harry. (2010). Komunikasi Manusia: Esensi dan Aplikasi dalam dinamika sosial ekonomi politik. Jakarta: Mitra Wacana Media.

Televisi, media yang paling banyak dikonsumsi milenial Indonesia. (2020, Januari 16). Februari 20, 2020.

Tripeni, Puput. (2017, September 23). Mengulik Nielsen Perusahaan Penghitung Rating Tv. Mei 20, 2020.

Wulandari, Shinta. (2019, November 22). Trans Tv Luncurkan 3 Program Baru. Mei 26, 2020. https://hot.detik.com/tv-news/d-4794663/trans-tv-luncurkan-3-program-baru

https://databoks.katadata.co.id/datapublish/2020/01/16/televisi-media-paling-banyakdikonsumsi-milenial-indonesia 
https://www.cnnindonesia.com/hiburan/20170922131852-220-243328/mengulik-nielsenperusahaan-penghitung-rating-televisi

https://www.tribunnews.com/nasional/jadwal-acara-tv-di-sctv-transtv-indosiar-rcti-metrotvnet- tv-hingga-rcti (data 22 November 2019 - 22 Februari 2020).

https://www.youtube.com/watch/oh-gitu 